\title{
Accumulation and Combined Effect of Salinity and Heavy Metals on Growth, Yield and Uptake of Green Pea Grown in Piped Hydroponics
}

\author{
M. N. Haddad and M. A. Al-Jada
}

ABSTRACT

This research is to study the accumulation and combined effect of three salinity levels $(750,1500$ and $3750 \mathrm{ppm})$ and of heavy metals $(3.26,3.2$, $2 \mathrm{ppm}, 2$, and $\mathrm{0.2}$ of $\mathrm{Zn}, \mathrm{Cu}, \mathrm{Fe}, \mathrm{Mn}$, and Mo, respectively) on growth, yield, and uptake of green pea plants grown in piped hydroponic. Due to freshwater shortages, the use of hydroponic growth system was encouraged and used. The experiment consists of planting green peas from seeds into a 6" PVC piped system. After 2.5 months of growing, the experiment was stopped and plants parts were separated and divided into pods, leaves, stems, and roots, Then, physical, and chemical measurements conducted on them. Results indicated that (1) Salt concentration above $1500 \mathrm{mg} / \mathrm{l}$ was detrimental on the growth of green pea, (2) the best growth, yield, and biomass weight were observed at salinity of $750 \mathrm{mg} / \mathrm{l}$, (3) heavy metals had positive effect on stems and roots of plants, but declined effect plant growth in general, (4) lines with nutrient deficiency were deficient in growth too, (5) sodium increased in plant's organs in response to increased salinity in the feed solution, (6) the largest concentration of copper and zinc were found at the roots of the highest salinity level lines $(36.05$ and $211.58 \mathrm{mg} / \mathrm{kg}$ dry plant, respectively), (7) the hydroponic system proved to be efficient and economical and therefore, it is recommended for use for Palestinian farmers, and (8) results obtained in this study agree with previously published research with extent differences.

Submitted : November 30, 2021

Published : December 28, 2021

ISSN: $2684-1827$

DOI: 10.24018 /ejfood.2021.3.6.424

\section{N. Haddad*}

Water and Environmental Studies Institute, An-Najah National University, Nablus, Palestine.

(e-mail: haddadm ${ }^{\circledR}$ najah.edu)

M. A. Al-Jada

Faculty of Graduate Studies, An-Najah

National University, Nablus, Palestine.

(e-mail: aljadasaba ${ }^{@}$ hotmail.com)

*Corresponding Author

Keywords: Green Pea, Salinity, Heavy Metals, Pipe Hydroponics.

\section{INTRODUCTION}

Green pea plant (Pisum sativum) is an important legume grown as a garden or field crop throughout the temperate regions worldwide. It is also grown 2522222as a cool-season crop or hill country crop in the tropics. It ranks third in production among the grain legumes after soybean and beans. Green pea is valued primarily for the nutritional quality of its seeds - green pea protein is rich in lysine and other essential amino acids but low in sulfur-containing amino acids, cysteine, and methionine [1].

Green peas seeds are characterized by the high proportion of protein and carbohydrates [2]. Green peas have the ability to fix nitrogen in the atmosphere by bacteria root nodules of the genus (Rhizobium). A process that leads to raise the fertility of the soil and increase the proportion of nitrogen out. Moreover, dry green pea seed is a rich source of protein (19$27 \%$ ) and is relatively free of anti-nutritional substances [3], [4].

Field crops including green peas are considered as important food for humans and animals in Palestine. The reported production of field crops in Palestine in 2010/2011 was 44,404 tons of which 2500 tons of green pea, while the total field crops planted area was 245,414 dunams [5]. The production of green pea in Palestine was reduced from 2276 tons in 2010 to2500 tons in 2012 [6].
Most of the crop plants are sensitive to salinity which is caused by high concentrations of salts in the irrigation water and consequently in soil. It was stated that more than 45 million hectares of irrigated land which account for $20 \%$ of total land, have been damaged by salt worldwide and 1.5 million hectares are taken out of production each year due to high salinity levels in the soil [7], [8].

In developing countries including the Palestinian Territory, the use of the hydroponic system in growing vegetable crops is encouraged and common due to scarcity of fresh water and its unavailability for irrigation.

Heavy metal concentrations of urban wastewater in the Palestinian Territory range from 0 to $2075 \mathrm{ppm}$ for zinc, 0 to10 ppm for copper, and from 0 to $15 \mathrm{ppm}$ for lead [9], [10]. Zinc has the highest level because galvanized steel tanks mounted on the roofs of buildings and houses are used in Palestine for water supply storage.

$\mathrm{Cu}, \mathrm{Zn}, \mathrm{Mn}, \mathrm{Fe}$, and $\mathrm{B}$ in irrigation water are essential micro-nutrients required for plant growth. These elements are heavy metals, and they may be toxic to plants if applied at high concentrations [9], [11]. Long-term application of salinity and such heavy metals in irrigation might in addition to affecting the plants themselves, end in polluting groundwater and soil [12], [13].

Water is an important element for all human activities including agriculture. Freshwater recourses in the world are very limited and only $0.6 \%$ of the total world water resources 
are freshwater [14]. Freshwater resources have been decreasing at an alarming rate due to the increase in population growth and associated growing demand for fresh water and they may not be able in the future to meet the requirements of the different human needs [15].

As a consequence, the increasing use of freshwater for domestic and industrial purposes has resulted in an increased volume of generated wastewater. Treated wastewater is increasingly viewed as a valuable supplementary water resource for the agricultural, industrial, and municipal sectors [16].

An assessment of groundwater in the Northern West Bank in Palestine for pollution with heavy metals was conducted. The concentration of $\mathrm{Cu}$ and $\mathrm{Zn}$ in the five wells were ranged from 0.52-16.11, 0.0-16.36 mg/l. However, all tested water samples were found to be within the US Environmental protection Agency and WHO limits [17].

The use of hydroponic system in green peas production in Palestine is important due to land area, irrigation water, and fertilizers use reduction. In addition, the control conditions in the hydroponic system would result greater production green peas even outside of the growing season.

Depending on the type of plant, the duration of exposure to the salinity, type of nutrients (elements and ions), and the stage of growth, the effect of salinity on plant production is very complicated, [18].

Salinity-induced nutritional disorders may be adversely affected crop performance. These may result from the effect of salinity on nutrient availability, competitive uptake, transport, or partitioning within the plant itself. For example, salinity reduces phosphate uptake and accumulation in crops grown in soils primarily by reducing phosphate availability but in solution cultures, ion imbalances may primarily result from competitive interactions [19]. Also, an increase in uptake and accumulation of $\mathrm{Cl}^{-}$is accompanied by a reduction in the concentration of $\mathrm{NO}_{3}{ }^{-}$in green pea plants [20], [21].

It was stated that with increasing salinity levels the response of nine green peas genotypes, under salt stress, root/shoot sodium $\left(\mathrm{Na}^{+}\right)$was increased. Tolerant genotypes under saline conditions were successful in maintaining the maximum dry matter, low $\mathrm{Na}^{+}$, while high $\mathrm{P}$ and $\mathrm{K}^{+}$[21].

It is concluded that the nitrogen source (ammonium or nitrate) is a major factor affecting green pea responses to saline stress, plants being more sensitive when ammonium is the source used [22]

Plants including green peas need some heavy metals such as $\mathrm{Fe}, \mathrm{Cu}$, and $\mathrm{Zn}$. These metals are essential for plants growth. The essential heavy metals play biochemical and physiological functions in plants. Two major functions of essential heavy metals are participation in redox reaction and direct participation, being an integral part of several enzymes [23].

Zinc $(\mathrm{Zn})$ is an essential micronutrient that affects several metabolic processes of plants including green peas [24], [25]. The phytotoxicity of $\mathrm{Zn}$ and $\mathrm{Cd}$ is indicated by the decrease in growth and development, metabolism, and induction of oxidative damage in various plant organs of green pea plants [26]. The threshold of $\mathrm{Zn}$ toxicity varies according to plant species, time of exposure to $\mathrm{Zn}$ stress, and composition of the nutrient growth medium. Green peas became inhibited after $1000 \mu \mathrm{M} Z \mathrm{Zn}$ application [27], [28]. Another typical effect of
$\mathrm{Zn}$ toxicity is the appearance of a purplish-red color in leaves, which is ascribed to phosphorus (P) deficiency [29], and transport chain [30].

Excess of $\mathrm{Cu}$ in irrigating water induces stress and causes injury to green peas. This leads to plant growth retardation and leaf chlorosis [31]. Also, exposure of green pea plants to excess $\mathrm{Cu}$ generates oxidative stress and ROS [32], [33].

Molybdenum helps in the fixation of atmospheric nitrogen by the root nodule bacteria. Legumes including green peas need more molybdenum to fix nitrogen than to utilize nitrates [34].

The objective of the present study is to assess the accumulation and combined effect of three salinity levels and heavy metals ( $\mathrm{Zn}, \mathrm{Cu}, \mathrm{Fe}, \mathrm{Mn}$, and Mo) on the growth, yield, and uptake of green pea plants grown in the closed piped hydroponic system.

\section{MATERIALS AND METHODS}

\section{A. Experimental Site and Program}

The experiment was divided into six lines. Every line consists of five pipes, so that each pipe accommodates four seedlings. Each growth line consists of 3.5 "holes for placing plastic pots, drainage holes 1" in diameter, internal spray lines, and nozzle sprayers (Fig. 1 and 2).

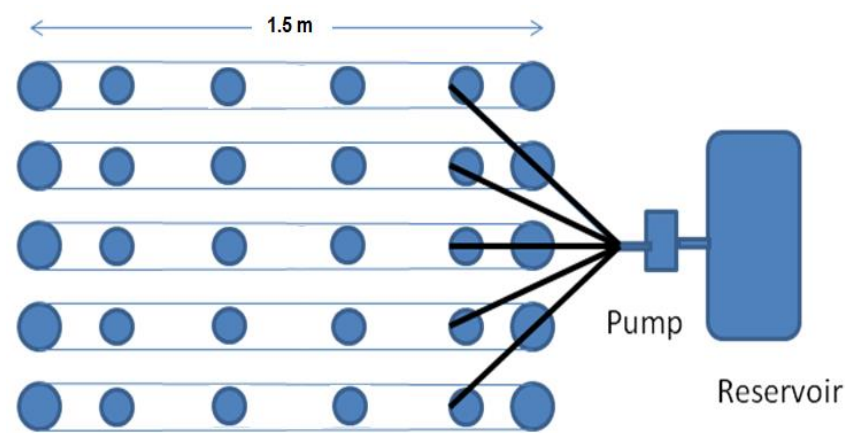

Fig. 1. Schematic of Piped Hydroponic system.

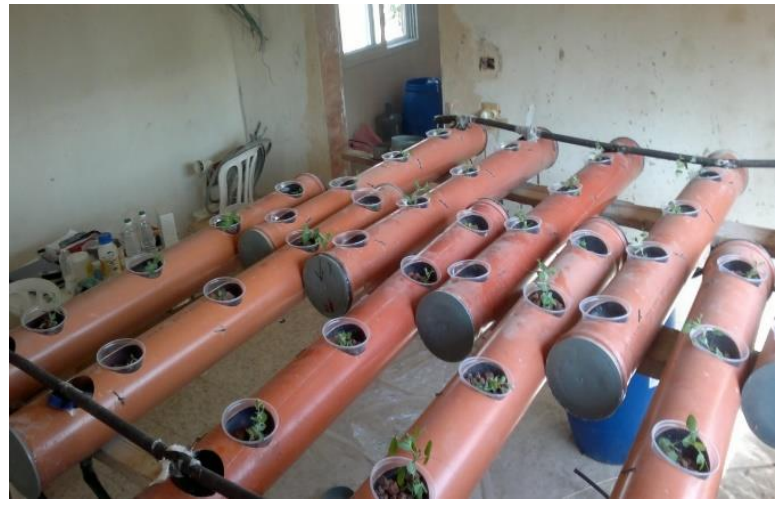

Fig. 2. Picture of Piped hydroponic system

The experimental program consists of the following steps:

- Green pea seeds were chosen from local agricultural market.

- Green peas seeds were planted in organic soil (ECO TERRA) for two weeks. At the end of the two weeks, they became about $5-7 \mathrm{~cm}$ in height.

- Seedlings are transferred to 4 "plastic pots filled with 0.5 " tuff (granite) stones and placed in the hydroponic growth system. 
- Green pea plants have been fixed to the plastic pipes with yarns and ropes so that seedlings grow in a vertical position. Plants were observed and measured continuously on a daily basis (see the section on measurements and laboratory analysis (see Fig. 3).

- The growth chambers containing tap water, and after a week of planting, tap water was replaced with the appropriate nutrient solution according to Table I.

- Growth of green peas in the hydroponic system continued for two months.

- The growth chambers containing tap water, and after a week of planting, tap water was replaced with the appropriate nutrient solution according to Table I.

- Growth of green peas in the hydroponic system continued for two months.

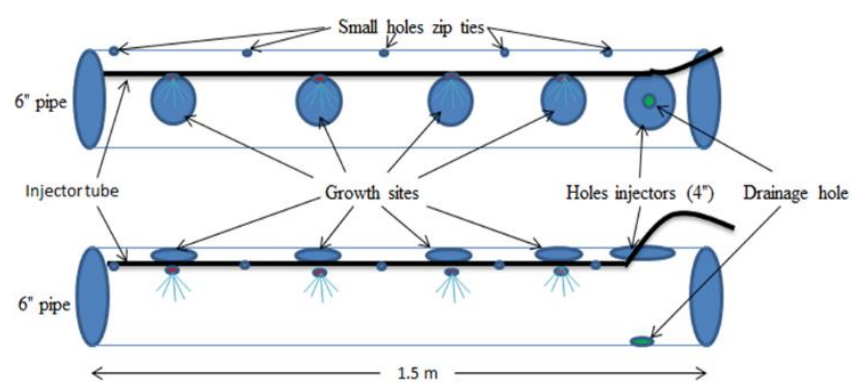

- $\quad$ Fig. 3. One Pipe Details of Piped hydroponic system.

\section{B. The Piped Hydroponic System}

The hydroponic growth system (HGS). HGS was constructed by using 6 inches plastic pipes with 1.5 meters length, Pipes were placed on a 1-meter wooden stand up the ground, and the system has provided irrigation water by pumps that pumped water from 120-liter plastic drums.

Nutrient solution was pumped to each pipe so that it was half-filled. Nutrient solutions in excess of this level flow back through the drainage holes to the 120-liter drum.

TABLE I: IRRIGATION WATER COMPOSITION

\begin{tabular}{cl}
\hline Line No. & \multicolumn{1}{c}{ Solution Composition* } \\
\hline 1 & 1 Cooper nutrient solution prepared plus 750 ppm salinity. \\
2 & 1/4 Cooper nutrient solution plus 750ppm salinity. \\
3 & Fresh water plus 750 ppm salinity. \\
4 & Fresh water plus $1500 \mathrm{ppm}$ salinity. \\
5 & Fresh water plus $3750 \mathrm{ppm}$ salinity. \\
6 & $\begin{array}{l}\text { 2.2 g Zinc Sulfate, } 1.93 \mathrm{~g} \text { Copper Sulfate, } 2.1 \mathrm{~g} \text { Iron-EDTA } \\
\text { plus 750 ppm salinity. }\end{array}$ \\
\hline *Note: Solutions were prepared according to Standard methods for the
\end{tabular}

examination of water and wastewater [35].

The third line was considered as the control line. The $750 \mathrm{ppm}$ salinity resembles the water The salinity level in the various regions and governorates of the West Bank and Gaza Strip in Palestine [36]. Cooper solution was prepared according to the concentrations shown in (Table II).

\begin{tabular}{ccccccc}
\multicolumn{6}{c}{ TABLE II: CONCENTRATION OF NUTRIENTS IN COOPER SOLUTION } \\
\hline Nutrients & $\mathrm{N}$ & $\mathrm{P}$ & $\mathrm{K}$ & $\mathrm{Ca}$ & $\mathrm{Mg}$ & $\mathrm{Fe}$ \\
\hline $\begin{array}{c}\text { Concentration } \\
(\mathrm{ppm})\end{array}$ & 200 & 60 & 300 & 170 & 50 & 12 \\
$\begin{array}{c}\text { Nutrients } \\
\text { Concentration } \\
(\mathrm{ppm})\end{array}$ & $\mathrm{Mn}$ & $\mathrm{Cu}$ & $\mathrm{Zn}$ & $\mathrm{B}$ & $\mathrm{Mo}$ & $\mathrm{S}$ \\
\hline
\end{tabular}

Source: Trejo-Téllez et al. [37].

\section{Measurements and Laboratory Analysis}

\section{1) Physical measurements of plants}

Through the experiment, length of seedlings was measured in $\mathrm{cm}$ once a week. Leaves, pods, and flowers of green peas were counted and were categorized into three classes: large, middle, and small. Leaves area was measured by counting squares on a special graph paper.

At the end of the growing season, all plants were harvested and cut into leaves, stems, pods, and roots.

Fresh stems, fresh leaves, fresh roots, and fresh pods were weighed by a sensitive electronic balance, then weighted plants' parts were placed in a furnace under $80{ }^{\circ} \mathrm{C}$ for two days in order to dry well. After plants' parts had been dried and weighed, the relative water content (RWC) was calculated.

\section{2) Chemical Laboratory analysis}

Dry ashing method was used on collected parts of green pea plants $[38,39]$. Equipment used in the laboratory analysis include Agilent 7500s ICPMS for the determination of heavy metals, Nitrate meter: HANNA Instrument, HI 93728-0, for nitrate analysis, and Spetronic 21D spectrophotometer for phosphate and sulfate determination. All chemical analysis (heavy metals, salinity, nutrients, plant parts solutions) was conducted according to Standard Methods for the examination of Water and Wastewater [35].

\section{Statistical Analysis}

Treatments in the experiment were arranged in a Completely Randomized Design (CRD), with five pipes, four replicate in each pipe. Collected data were subjected to the analysis of variance (one way ANOVA) using SPSS program version 21 [40]. Means separated will be used to Tukey HSD at 0.05 level of probability. Microsoft EXCEL 2010 was used in data analysis, and Pearson correlation is used to find the relation between the concentrations of nutrients and sampling dates.

\section{RESUlTS AND DISCUSSION}

Due to the size of the work done, results pertain to salinity and heavy metals impacts on green peas will only be reported in this section (lines 3, 4, 5, and 6 in Table III). Other results will be reported in another publication.

\section{A. Characteristics of Plants}

Green pea growth results and morphological characteristics including pods, leaves, stems, and roots are reported in the following sections to determine the impact of the above factors on plants.

\section{1) Survival percentage}

Table III include average salinity and survival percentage in the various experimental lines. A Green Pearson productmoment correlation was run to determine the relationship between salinity levels and germination percentage. The data showed strong, negative correlation between salinity levels and germination percentage, which was statistically significant $(r=-0.999, p<0.05)$. 
TABLE III: RELATIONSHIP BETWEEN SURVIVAL PERCENTAGE OF GREEN Pea Plant AND SAlinity LEVEls (MS/CM)

\begin{tabular}{ccc}
\multicolumn{2}{c}{ PEA PLANT AND SALINITY LEVELS (MS/CM) } \\
\hline Line number & $\begin{array}{c}\text { Average Salinity, } \\
\text { ms/cm, (ppm) }\end{array}$ & $\begin{array}{c}\text { Survival } \\
\text { percentage \% }\end{array}$ \\
\hline Line 3 & $2.61(1305)$ & 90 \\
Line 4 & $4.07(2035)$ & 80 \\
Line 5 & $8.01(4005)$ & 50 \\
Line 6 & $2.58(1290)$ & 70 \\
\hline
\end{tabular}

\section{2) Pods characteristics}

The number and fresh and dry biomass weight of the pods of green pea plants in different lines are listed in Table IV.

TABLE IV: THE AVERAGE NUMBER, FRESH AND DRY BIOMASS WEIGHT OF PODS IN DIFFERENT LINES.

\begin{tabular}{cccc}
\hline Treatment & $\begin{array}{c}\text { Average } \\
\text { number of } \\
\text { pods }\end{array}$ & $\begin{array}{c}\text { Fresh pods } \\
\text { weight } \\
\text { (gram/plant) }\end{array}$ & $\begin{array}{c}\text { Dry pods } \\
\text { weight } \\
\text { (gram/plant) }\end{array}$ \\
\hline Line 3 & $1.17 \mathrm{~b}$ & $2.16 \mathrm{c}$ & $0.3983 \mathrm{c}$ \\
Line 4 & $1.20 \mathrm{~b}$ & $1.10 \mathrm{~cd}$ & $0.202 \mathrm{~d}$ \\
Line 5 & -------- & ----- & ----- \\
Line 6 & $0.35 \mathrm{c}$ & $0.022 \mathrm{de}$ & $0.014 \mathrm{de}$ \\
\hline
\end{tabular}

Note: Averages in columns with the same small letters are not significantly different at $\mathrm{P} \leq 0.05$ level, according to Tukey HSD.

It has been observed the number and fresh and dry weight increased significantly in the number of pods and weight decreased significantly when salinity in the nutrient solution is increased (Line 5 less than Line 4 and Line 4 less than Line 3 ), but number of green pea pods has increased in Line 4 plants(contained $1500 \mathrm{ppm} \mathrm{NaCl}$ ) compared with Line 3 (contained $750 \mathrm{ppm} \mathrm{NaCl}$ ), it may be due to a period of premature aging and to maintain the life cycle physiologically, and this result supports the findings of [44] and in plants of Line 6 (contained heavy metals) was owned pod and fresh and dry biomass pods weight less than Line 3 (Control Line), while Line 5 plants (containing 3750 ppm $\mathrm{NaCl}$ ) hadn't produced any pods, it can be seen clearly in (Table IV).

Increasing the salinity of the nutrient solution led to stress the plants and then lead to low and poor metabolic processes and the performance of plants. The number and fresh and dry biomass of pods green pea plant were increased significantly in Line 3 more than Line 4 , Line 4 more than Line 5, that is consistent with [22], [41].

Results of line 6 were much less than other lines due to the negative impact of heavy metals on plant growth.

\section{3) Leaves characteristics}

The area, fresh and dry biomass weight of the leaves of green pea plants are reported in Table V. As shown in Table $\mathrm{V}$, as salinity increase the area of leaves, fresh and dry weight decreases. Similar effect on leave area was observed by heavy metal content but, fresh and dry weight of leaves in line six with heavy metal showed no negative effect.

TABLE V: AVERAGE THE AREA, FRESH AND DRy Biomass WeIGHT OF LEAVES GREEN PEA PLANTS AT DIFFERENT LINES

\begin{tabular}{cccc}
\hline Treatment & $\begin{array}{c}\text { Area of leaves } \\
\left(\mathrm{cm}^{2}\right)\end{array}$ & $\begin{array}{c}\text { Fresh leaves } \\
\text { weight } \\
(\mathrm{g} / \mathrm{plant})\end{array}$ & $\begin{array}{c}\text { Dry leaves } \\
\text { weight } \\
(\mathrm{g} / \mathrm{plant})\end{array}$ \\
\hline Line 3 & $23.44 \mathrm{bc}$ & $0.41 \mathrm{c}$ & $0.095 \mathrm{c}$ \\
Line 4 & $17.67 \mathrm{bc}$ & $0.38 \mathrm{c}$ & $0.089 \mathrm{bc}$ \\
Line 5 & $8.90 \mathrm{c}$ & $0.23 \mathrm{c}$ & $0.042 \mathrm{bc}$ \\
Line 6 & $8.14 \mathrm{c}$ & $0.36 \mathrm{c}$ & $0.075 \mathrm{c}$ \\
\hline
\end{tabular}

Note: Averages in columns with the same small letters are not significantly different at $\mathrm{P} \leq 0.05$ level, according to Tukey HSD.

\section{4) Stems characteristics}

The length and fresh and dry biomass weight of the stems of green pea plants at different lines are reported in Table VI. Analysis of variance (ANOVA) indicated that the stem measurements were significantly different $(\alpha \leq 0.05)$. It was also found that the stem measurements decreased with increased salinity. These results are consistent with [21], [22], [41].

Slight impact was observed in the heavy metal line. These results are consistent with previous studies [23].

\begin{tabular}{cccc} 
TABLE VI: AVERAGE LENGTH, FRESH AND DRY WEIGHT OF STEM \\
\hline Treatment & $\begin{array}{c}\text { length of } \\
\text { stems }(\mathrm{cm})\end{array}$ & $\begin{array}{c}\text { Fresh stems } \\
\text { weight } \\
\text { (g/plant) }\end{array}$ & $\begin{array}{c}\text { Dry stems } \\
\text { weight } \\
\text { (g/plant) }\end{array}$ \\
\hline Line 3 & $19.25 \mathrm{c}$ & $0.58 \mathrm{c}$ & $0.094 \mathrm{bc}$ \\
Line 4 & $15.80 \mathrm{~cd}$ & $0.41 \mathrm{~cd}$ & $0.087 \mathrm{bc}$ \\
Line 5 & $14.20 \mathrm{~d}$ & $0.21 \mathrm{~d}$ & $0.048 \mathrm{c}$ \\
Line 6 & $20.21 \mathrm{bc}$ & $0.30 \mathrm{~cd}$ & $0.058 \mathrm{bc}$ \\
\hline
\end{tabular}

Note: Averages in columns with the same small letters are not significantly different at $\mathrm{P} \leq 0.05$ level, according to Tukey HSD.

\section{5) Roots characteristics}

The length, fresh and dry biomass weight of the roots of green pea plants at different lines are reported in Table VII. Analysis of variance (ANOVA) the (Table VII) shows the average length, fresh and dry biomass weight of the roots at different lines, the average of measurements was significantly differed at $(\alpha \leq 0.05)$. No specific trend was found between root measurements and either salinity and/or heavy metals in the lines 3, 4 and 6 . The very high salinity of line 5 did negatively and clearly impact root growth.

TABLE VII: AVERAGE LENGTH, FRESH AND DRY BIOMASS OF ROOTS GREEN PEA PLANTS AT DIFFERENT LINES

\begin{tabular}{cccc}
\hline $\begin{array}{c}\text { Line } \\
\text { number }\end{array}$ & $\begin{array}{c}\text { Length of roots } \\
(\mathrm{cm})\end{array}$ & $\begin{array}{c}\text { Fresh roots } \\
\text { weight }(\mathrm{g} / \mathrm{plant})\end{array}$ & $\begin{array}{c}\text { Dry roots } \\
\text { weight }(\mathrm{g} / \mathrm{plant})\end{array}$ \\
\hline Line 3 & $17.25 \mathrm{bc}$ & $0.46 \mathrm{bc}$ & $0.049 \mathrm{bc}$ \\
Line 4 & $22.73 \mathrm{ab}$ & $0.47 \mathrm{bc}$ & $0.073 \mathrm{~b}$ \\
Line 5 & $9.80 \mathrm{c}$ & $0.15 \mathrm{c}$ & $0.034 \mathrm{c}$ \\
Line 6 & $21.07 \mathrm{ab}$ & $0.22 \mathrm{c}$ & $0.039 \mathrm{bc}$ \\
\hline
\end{tabular}

Note: Averages in columns with the same small letters are not significantly different at $\mathrm{P} \leq 0.05$ level, according to Tukey HSD and Multiple Comparisons

\section{B. The Overall Effect of Salinity on Green Pea Plants}

The overall results of fresh and dry plant weight of green pea for the different lines are reported in Table VIII. It is clear that fresh and dry plant weight was affected by salinity increase as well as heavy metal presence in the irrigation water. These results are in agreement with [28]. Analysis of variance (ANOVA) at $(\alpha \leq 0.05)$, showed that there are differences in the average of biomass plants at different salinities.

TABLE VIII: AVERAGE Fresh AND DRY WeIght OF WhOle Plant oF GREEN PEA AT DIFFERENT SALINITIES (ELECTRICAL CONDUCTIVITY (EC)

\begin{tabular}{ccccc}
\multicolumn{5}{c}{ OF VARIOUS LINES) } \\
\hline Treatment & $\begin{array}{c}\text { EC } \\
(\mathrm{ms} / \mathrm{cm})\end{array}$ & $\begin{array}{c}\text { Fresh plant } \\
\text { weight } \\
\text { (gram/plant) }\end{array}$ & $\begin{array}{c}\text { Dry plant } \\
\text { weight } \\
\text { (gram/plant) }\end{array}$ & $\begin{array}{c}\text { RWC } \\
(\%)\end{array}$ \\
\hline Line3 & 2.61 & $3.27 \mathrm{c}$ & $0.58 \mathrm{c}$ & $82.20 \mathrm{~b}$ \\
Line4 & 4.07 & $2.39 \mathrm{~cd}$ & $0.46 \mathrm{c}$ & $80.84 \mathrm{bc}$ \\
Line5 & 8.01 & $0.60 \mathrm{de}$ & $0.13 \mathrm{~d}$ & $79.10 \mathrm{~d}$ \\
Line6 & 2.58 & $0.71 \mathrm{e}$ & $0.14 \mathrm{~d}$ & $80.61 \mathrm{~cd}$ \\
\hline
\end{tabular}

Note: Averages in columns with the same small letters are not significantly different at $\mathrm{P} \leq 0.05$ level, according to Tukey HSD. 


\section{Heavy Metals Effects}

\section{1) Copper}

The average concentration of copper ion $\mathrm{Cu}^{+2}$ in all parts of green pea plants at different lines is reported in Table IX. It was observed that the concentration of copper has decreased in all plant parts when salinity increased in nutrient solutions. The copper increase was the highest in roots then stems, then leaves, and last in leaves. However, when heavy metals were added (line 6) the copper concentration significantly increased from the roots up to the pods. This increase indicates the green pea stress-free uptake of copper from irrigation water. This result is in agreement with previous studies [22], [41].

It is found that the significance level is $(\mathrm{p}<0.05)$ and there are statistically significant differences in the mean copper weights at different plant parts.

TABLE IX: Average WeIght OF COPPER (Mg/KgDry Plant) IN ALL PARTS OF GREEN PEA PLANTS AT DIFFERENT LINES

\begin{tabular}{ccccc}
\hline Line No. & Pods & Leaves & Stems & Roots \\
\hline Line 3 & $10.44 \mathrm{~d}$ & $12.76 \mathrm{~d}$ & $11.8 \mathrm{~d}$ & $14.45 \mathrm{~d}$ \\
Line 4 & $9.40 \mathrm{~d}$ & $12.2 \mathrm{~d}$ & $10.17 \mathrm{de}$ & $12.79 \mathrm{de}$ \\
Line 5 & - & $9.1 \mathrm{de}$ & $9.09 \mathrm{e}$ & $10.32 \mathrm{e}$ \\
Line 6 & $26.93 \mathrm{a}$ & $33.48 \mathrm{a}$ & $30.32 \mathrm{a}$ & $36.05 \mathrm{a}$ \\
\hline
\end{tabular}

Note: Averages in columns with the same small letters are not significantly different at $\mathrm{P} \leq 0.05$ level, according to Tukey HSD.

\section{2) Iron}

The average concentration of Iron ion $\mathrm{Fe}^{+3}$ in all parts of green pea plants at different lines are presented in Table X. It was observed that the concentration of Iron in Green Pea parts (stem, leaves, and pods) has decreased when salinity increased in nutrient solution while in roots no effect of salinity on Iron accumulation was observed. It was noted that when the salinity was highest in nutrient solution (line 5), Iron concentration increased significantly in all green pea parts (no reports of iron in pods because there were no pods showed in green pea plants at such salinity).

TABlE X: Average Weight of Iron (Mg/KgDry Plant) In All Parts

\begin{tabular}{ccccc}
\multicolumn{5}{c}{ OF GREEN PEA PLANTS AT DIFFERENT LINES } \\
\hline Line No. & Pods & Leaves & Stems & Roots \\
\hline Line 3 & $17.46 \mathrm{c}$ & $44.25 \mathrm{~d}$ & $37.86 \mathrm{c}$ & $16.34 \mathrm{c}$ \\
Line 4 & $9.00 \mathrm{~d}$ & $19.20 \mathrm{e}$ & $18.18 \mathrm{~d}$ & $14.67 \mathrm{c}$ \\
Line 5 & - & $26.63 \mathrm{e}$ & $24.95 \mathrm{~cd}$ & $15.19 \mathrm{c}$ \\
Line 6 & $31.88 \mathrm{~b}$ & $98.22 \mathrm{c}$ & $96.96 \mathrm{~b}$ & $23.46 \mathrm{~b}$ \\
\hline
\end{tabular}

Note: Averages in columns with the same small letters are not significantly different at $\mathrm{P} \leq 0.05$ level, according to Tukey HSD.

ANOVA analysis revealed that the significance level is $(\mathrm{p}<0.05)$ and there is a significant difference in the mean iron weight at different plant parts.

When heavy metals were added (line 6) Iron concentrations in green pea parts were significantly higher than the response to salinity addition. However, this increase is not consistent in all parts, higher Iron accumulated in stem and leaves than roots and pods.

This increase indicates the green pea stress-free uptake of Iron from irrigation water and that Iron moved from roots and accumulated in stem and leaves. This result is in agreement with previous studies [22], [41], [42].

\section{3) Manganese}

The average concentration of manganese ion $\left(\mathrm{Mn}^{+2}\right)$ in all parts of green pea plants at different lines is presented in Table XI. It was observed that the manganese concentration in all green pea parts decreased in response to salinity increase in nutrient solutions. The increase was the highest in roots then stem and leaves, and last in the pods. It was also observed that the concentration of manganese has increased slightly in Line 5 than Line 4, these results are consistent with the findings of each [22], [41], [42].

No specific impact of heavy metal addition was observed on the accumulation of Manganese in green pea parts.

TABLE XI: Average Weight of MANGANESE (Mg/KgDry Plant) IN

\begin{tabular}{ccccc}
\multicolumn{4}{c}{ ALL PARTS OF GREEN PEA PLANTS AT DIFFERENT LINES } \\
\hline Line No. & Pods & Leaves & Stems & Roots \\
\hline Line 3 & $17.66 \mathrm{c}$ & $22.10 \mathrm{c}$ & $21.72 \mathrm{c}$ & $25.22 \mathrm{c}$ \\
Line 4 & $16.30 \mathrm{~d}$ & $19.10 \mathrm{~d}$ & $18.76 \mathrm{~d}$ & $22.27 \mathrm{~d}$ \\
Line 5 & ---- & $20.05 \mathrm{~cd}$ & $19.77 \mathrm{~cd}$ & $19.61 \mathrm{e}$ \\
Line 6 & $17.02 \mathrm{c}$ & $22.32 \mathrm{c}$ & $21.48 \mathrm{c}$ & $20.95 \mathrm{de}$
\end{tabular}

Note: Averages in columns with the same small letters are not significantly different at $\mathrm{P} \leq 0.05$ level, according to Tukey HSD.

ANOVA analysis that the significance level is $(\mathrm{p}<0.05)$ and there are statistically significant differences in the mean Manganese weights at different plant parts in response to salinity addition.

4) Zinc

The average concentration of zinc ion $\left(\mathrm{Zn}^{+2}\right)$ in all parts of green pea plants at different lines is presented in Table XII. It has been observed that the concentration of Zinc has decreased in all plant parts as a response to salinity increase in nutrient solution. It was also observed that the concentration of zinc in the roots are more than leaves, stems, and pods. The Zinc concentration increase at high salinity level in irrigation water was slight (line 5). Accumulation of Zinc in stems and leaves were higher in line 5 than 3 and 4.

Green pea response to heavy metal addition and uptake of Zinc in all parts of the plant (line 6) was much higher than that when salinity was added. This result confirms with previous results of heavy metal and emphasize the high ability of green pea to absorb heavy metal.

TABLE XII: AVERAgE WeIGHT OF ZinC (MG/KgDRy Plant) IN ALL PARTS OF GREEN PEA PLANTS AT DIFFERENT LINES

\begin{tabular}{ccccc}
\hline Line No. & Pods & Leaves & Stems & Roots \\
\hline Line 3 & $22.56 \mathrm{~cd}$ & $30.34 \mathrm{c}$ & $30.13 \mathrm{~d}$ & $50.38 \mathrm{~cd}$ \\
Line 4 & $20.01 \mathrm{~d}$ & $26.01 \mathrm{~d}$ & $24.28 \mathrm{e}$ & $43.96 \mathrm{~d}$ \\
Line 5 & ----- & $32.81 \mathrm{bc}$ & $32.26 \mathrm{~cd}$ & $39.44 \mathrm{~d}$ \\
Line 6 & $45.79 \mathrm{a}$ & $161.25 \mathrm{a}$ & $162.40 \mathrm{a}$ & $211.58 \mathrm{a}$ \\
\hline
\end{tabular}

Note: Averages in columns with the same small letters are not significantly different at $\mathrm{p} \leq 0.05$ level, according to Tukey HSD.

ANOVA analysis showed that the significance level is $(p<0.05)$ and there are significant differences in the mean zinc weights at different plant parts.

\section{5) Molybdenum}

The average concentration of Molybdenum ion $\left(\mathrm{Mo}^{+6}\right)$ (mg/kg dry plant) in all parts of green pea plants at different lines is presented in Table XIII. It was observed that the response of green pea to different salinity additions in irrigation water was not systematic without any trend. The concentration of Molybdenum was increased slightly in green pea plants of Line 5 in comparison with Line 3 and Line 4. 
The concentration of Molybdenum in green pea roots was close under the various treatments including the addition of heavy metals.

TABLE XIII: AVERAgE CONCENTRATION OF MOLYBDENUM (MG/KGDRY Plant) In All PARTs Of GREEN PEA Plants AT DifFERENT LiNES

\begin{tabular}{ccccc}
\hline Line No. & Pods & Leaves & Stems & Roots \\
\hline Line 3 & $0.46 \mathrm{c}$ & $0.57 \mathrm{~d}$ & $0.73 \mathrm{~cd}$ & $0.55 \mathrm{~d}$ \\
Line 4 & $0.40 \mathrm{~cd}$ & $0.54 \mathrm{de}$ & $0.71 \mathrm{~cd}$ & $0.51 \mathrm{~d}$ \\
Line 5 & - & $0.57 \mathrm{~d}$ & $0.83 \mathrm{c}$ & $0.61 \mathrm{~cd}$ \\
Line 6 & $0.37 \mathrm{~d}$ & $0.90 \mathrm{c}$ & $0.66 \mathrm{~d}$ & $0.69 \mathrm{c}$
\end{tabular}

Note: Averages in columns with the same small letters are not significantly different at $\mathrm{P} \leq 0.05$ level, according to Tukey HSD.

ANOVA analysis showed that the significance level is ( $\mathrm{p}$ $<0.05)$ and that there are significant differences in the mean molybdenum concentrations at different plant parts.

\section{CONCLUSION}

Based on the results obtained in this study, the following concluding remarks were derived:

- There was strong negative correlation between irrigation water salinity and green peas germination (survival rate).

- Growth including fresh and dry weight and yield of green peas parts has negatively affected by high levels of salinity to the level of no pods production at 3750 ppm salinity.

- It was determined that green peas could be grown in a nutrient solution with salinity of 1500 ppm or less.

- Heavy metal presence ( $\mathrm{Cu}, \mathrm{Fe}, \mathrm{Zn}, \mathrm{Mn}$, and $\mathrm{Mo}$ ) in the irrigation water has negatively affected green pea growth.

- Low concentration of both copper and zinc could be used to increase the growth of roots and stems of green peas.

- The high accumulation of heavy metal in green pea's parts from roots to pods show heavy metal removal effectiveness encourages the use of green peas in phytoremediation.

- The piped hydroponic system proved to be efficient and practical for planting green peas and it is therefore recommended for Palestinian farmers.

\section{CONFLICT OF INTEREST}

Authors declare that they do not have any conflict of interest.

\section{REFERENCES}

[1] Christou P. The biotechnology of crop legumes. Euphytica, 1994; 74:165-185.

[2] Choudhury P, Tanveer H, Dixit G. Identification and detection of genetic relatedness among important varieties of green pea (Pisum sativum L.) grown in India. Genetica, 2007; 130:183-191.

[3] Rowland I, Mason M, Pritchard I, French R. Effect of field green peas and wheat on the yield and protein of subsequent wheat crops grown at several rates of applied nitrogen. Aus. J. Exp. Agric., 1994; 34:641646.

[4] Petterson.S, Mackintosh B. The chemical composition and nutritive value of Australian grain legumes. Grains Research and Development Corporation, 1994; 4:1-68.

[5] The Palestinian Central Bureau of Statistic, PCBS. Area and Production of Field Crops in Palestine by Type of Irrigation and
Governorate, 2010/2011. Available from: https://pcbs.gov.ps/Portals/_Rainbow/Documents/Agri.20102011,19E.htm. Accessed November 2021.

[6] Food and Agriculture Organization Corporate Statistical Database, FAOSTAT. Production/Crops. Available from: http://faostat3.fao.org/ download/Q/QC/E

[7] Pitman G, Lauchli A. Global impact of salinity and agricultural ecosystems. In: Lauchli A, Luttge $U$ (eds) Salinity: environment plants-molecules. Kluwer, Dordrecht, 2002, pp. 3-20.

[8] Munns R, Tester M. Mechanisms of salinity tolerance. Annu. Rev. Plant Biol. 2008; 59:651-681.

[9] Haddad M, Abu Jaish A. The Occurrence and the Future of Trace Metals in Wastewater Streams in the West Bank. Proceedings of the $3 r d$ International Conference on Energy and Environmental Protection in Sustainable Development (ICEEP III) --session IV-B, 2013, pp:285300.

[10] Haddad M, Mizyed N, Abu Qaoud H. Individual and Combined Effects of Lead, Zinc, Nickel, and Cadmium on the growth and Uptake of Metals by Eggplants. Proceedings of the Dahlia Griendinger International Symposium on Nutrient Management under Salinity and Water Stress, March 1999, pp 23-33.

[11] Parveena T, Hussain A, Rao S. Growth and accumulation of heavy metals in turnip (Brassica rapa) irrigated with different concentrations of treated municipal wastewater. Hydrol Res, 2015; 46-1:60-71.

[12] Al-Subu M, Haddad M, Mizyed N, Mizyed I. Impacts of Irrigation with Water Containing Heavy Metals on Soil and Groundwater, A simulation study. Water, Air, and Soil Pollution, 2003;146: 141-152.

[13] Yurtseven, E. Salinity management in irrigated areas, concepts, and principles. Proceedings of Salinity in Irrigated Areas Management Symposium", General Directorate of State Hydraulic Works, 2004, pp 17- 48.

[14] Fakayode, O. Impact of industrial effluents on water quality of the receiving Alaro River in Ibadan, Nigeria. Ajeam-Ragee. 2005;10:1-13.

[15] Qadir M, Wichelns L, Raschid-Sally G, McCornick P, Drechsel B Minhas S. The challenges of wastewater irrigation in developing countries. Agric. Water Management, 2008; Available from: http://www. sciencedirect.com.

[16] Darvishi H, Manshour M, Farahani A. The effect of irrigation by domestic wastewater on the soil. J. Soil Sci. Environ. Manage. 2010;1, 30-33.

[17] Malassa M, Hadidoun M, Al-Khatib F, Al-Rimawi M, Al-Qutob M Assessment of Groundwater Pollution with Heavy Metals in North West Bank/Palestine by ICP-MS. Journal of Environmental Protection, 2014; 5-1:54-59.

[18] Gunes A, Alpaslan M, Inal A. Plant nutrition and fertilization. Ankara University, Agricultural Faculty Publication No. 1514, 2000; P. 576, Ankara, Turkey.

[19] Grattan R, Grieve M. Mineral nutrient acquisition and the response of plants grown in saline environments". In: Handbook of Plant and Crop Stress, M. Pessarakli, (Ed.), Marcel Dekker Press Inc., New York, 1999; pp:203-229.

[20] Shahid M, Pervez M, Ashraf M, Ayyub M, Ashfaq M, Mattson N. Characterization of Salt Tolerant and Salt Sensitive Green pea (Pisum sativum L.) Genotypes under Saline Regime. Pak. J. life soc. Sci., 2012; 9-2:145-152

[21] Shahid M, Ashraf M, Perevz M, Ahmad R, Bala R, Sanchez F. Impact of Salt Stress on Concentrations of $\mathrm{Na}^{+}, \mathrm{Cl}^{-}$and Organic Solutes Concentration in Green pea Cultivars". Pak. J. Bot., 2013; 45-3: 755761.

[22] Yorgancilar M, Gül Yeðin Z. The effect of different salt concentrations on the root and stem nutrient contents of green pea (Pisum sativum $L$. cv. Jofs). J. Food, Agri. Environ, 2012;10-1: 605-607.

[23] Nagajyoti P, Lee K, Sreekanth T. Heavy metals, occurrence, and toxicity for plants. Environ. Chem. Lett. 2010; 8:199-216. DOI: 10.1007/s10311-010-0297-8.

[24] Cakmak I., Marshner H. Effect of zinc nutritional status on superoxide radical and hydrogen peroxide scavenging enzymes in bean leaves. In: Barrow N.J. (ed.) Plant nutrition-from genetic engineering field practice. Kluwer, The Netherlands, 1993. pp 133-137.

[25] Fageria K. Influence of micronutrients on dry matter yield and interaction with other nutrients in annual crops. Pesq. Agropec. Bras. 2002;37:1765-1772.

[26] Romero-Puertas C, Rodriquez-Serrano M, Corpas J, Gomez M, Del Rio A, Sandalio M. Cadmium-induced subcellular accumulation of $\mathrm{O}_{2}$ and $\mathrm{H}_{2} \mathrm{O}_{2}$ in green pea leaves. Plant Cell Environ, 2004; 27:1122-1134.

[27] Doncheva Z, Stoyanova V. Influence of succinate on zinc toxicity of pea plants. J. Plant Nutr., 2001;. 24- 6:789-804

[28] Stoyanova Z, Doncheva S. The effect of zinc supply and succinate treatment on plant growth and mineral uptake in pea plant. Braz. J. Plant Physiol., 2002; 14-2:111-116. 
[29] Lee W, Choi M, Pak H. Micronutrient toxicity in seed geranium (Pelargonium 9 hortorum Baley). J. Am. Soc. Horti. Sci., 1996; 121:7782.

[30] Demirevska-Kepova K, Simova-Stoilova L, Stoyanova Z, Holzer R, Feller U. Biochemical changes in barley plants after excessive supply of copper and manganese. Environ. Exp. Bot., 2004;52, 253-266.

[31] Lewis S, Donkin E, Depledge H. Hsp 70 expression in Enteromorpha intestinalis (Chlorophyta) exposed to environmental stressors. Aqua Toxicol., 2001; 51:277-291.

[32] Malecka A, Piechalak A, Zieliñska B, Kutrowska A, Tomaszewska B. Response of the green pea roots defense systems to the two-element combinations of metals $(\mathrm{Cu}, \mathrm{Zn}, \mathrm{Cd}, \mathrm{Pb})$. ACTA Biochim. Pol., 2014; 61-1:23-28.

[33] Stadtman, R, Oliver N. Metal-catalyzed oxidation of proteins, 1991; 266(4):2005-2008.

[34] Hristozkova M, Geneva M, Stancheva I. Response of Pea Plants (Pisum sativum L.) to Reduced Supply with Molybdenum and Copper. Int. J. Agri. Biol., 2006; 8-218-220.

[35] American Public Health Association, APHA, American Water Works Association, AWWA, and Water Environment Federation WEF, (2017). Standard Methods for the Examination of Water and Wastewater, 23 edition. Washington DC. Available from: standardmethods.org.

[36] Jebreen H, Wohnlich S., Banning A, Wisotzky, F, Hachenberg A Ghanem M. Recharge, geochemical processes and water quality in karst aquifers: Central West Bank, Palestine. Environmental Earth Sciences, 2018; 77- 6:1-13.

[37] Trejo-Téllez I, Gómez-Merino C, Alcántar G. Elementos Benéficos, En: Nutrición de Cultivos, G. Alcántar G \& L. I. Trejo-Téllez, L. I. (Eds.), pp:50-91.

[38] Gorsuch T. Sample preparation using the dry-ashing method, Analyst, 1959, Ch. 84, pl05.

[39] The International Center for Agricultural Research in the Dry Areas, ICARDA. Methods of Soil, Plant, and Water Analysis: A manual for the West Asia and North Africa region, George Estefan, Rolf Sommer, and John Ryan, $3^{\text {th }} E d$., 2001. Available from: https://hdl.handle.net/20.500.11766/7512.

[40] IBM Corp. IBM SPSS Statistics for Windows, Version 21.0. Armonk, NY: IBM Corp, 2012.

[41] Nenova, V. Effect of Iron Supply on Growth and Photosystem II Efficiency of Pea Plants". Gen. Appl. Plant Physiol., Special Issue, 2006; pp:81-90.

[42] Tavori G, Abbo S, Kafkafi U, Schnug E. Influence of nitrate- and sodium chloride on concentration and internal distribution of mineral elements in broad bean (Vicia faba L.) and chickpea (Cicer arietinum L.). In: Landbauforschung Volkenrode (FAL Agricultural Research), 2004; 54- 4: 189-197.

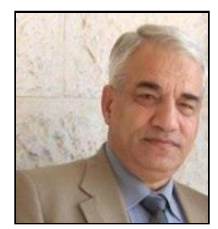

M. N. Haddad Prof. Marwan Haddad is a ful professor of environmental engineering since 1999 and Chaired Civil Engineering Department (19861992), hold the deanship of the Faculty of Engineering, and established (1996-1998) and directed Water and Environmental Studies Institute (WESI) at An-Najah National University (ANU) in Nablus (1994-1996, and 2008 to 2017). He worked as project engineer at the housing corporation, Amman, Jordan (19761980). He has a multidisciplinary background that includes a MSc in Structural Civil Engineering, a MSc in Sanitary Engineering and a PhD in Environmental Civil Engineering, complemented by over 40 years of professional experience in the Mediterranean region in the water, sanitation, and environmental sector. He has a solid understanding of the water sector's stakes, challenges and development opportunities, mainstreaming adaptation and mitigation strategies and policies in development plans and water management with IFIs and international organisations. He led tens of national and regional study teams and projects related to water and sanitation. He has published more than 230 technical papers in national and international journals and has participated in hundreds of seminars, conferences and workshops, showing the water situation and providing institution-building initiatives nationally, regionally, and internationally. 